\title{
Effects of Steam Treatment on Physical and Mechanical Properties of Bamboo Oriented Strand Board ${ }^{1}$
}

\author{
Sena Maulana ${ }^{2}$ Imam Busyra ${ }^{2}$ - Adesna Fatrawana ${ }^{2}$ Wahyu Hidayat ${ }^{3} \cdot$ Rita Kartika Sari $^{2}$. \\ Ihak Sumardi ${ }^{4} \cdot$ I Nyoman Jaya Wistara ${ }^{2} \cdot$ Seung Hwan Lee ${ }^{5} \cdot$ Nam Hun Kim $\mathbb{D}^{5, \dagger} \cdot$ Fauzi Febrianto (D) ${ }^{2, \dagger}$
}

\begin{abstract}
The objective of this study was to evaluate the properties of bamboo oriented strand board (B-OSB) from andong (Gigantochloa psedoarundinacea) and betung (Dendrocalamus asper) with and without steam treatment. Strands were steam-treated at $126^{\circ} \mathrm{C}$ for $1 \mathrm{~h}$ under $0.14 \mathrm{MPa}$ pressure. The extractive content of bamboo strands before and after steam treatment were determined according to a standard (TAPPI T $204 \mathrm{om}-88$ ). Three-layer B-OSB with the core layer perpendicular to the surface and back layers were formed and binded with $8 \%$ of phenol formaldehyde (PF) resin with the addition of $1 \%$ of wax. The evaluation of physical and mechanical properties of the boards were conducted in accordance with the JIS A 5908:2003 standard. The results showed that steam treatment of bamboo strands significantly reduced the extractive content. Steam treatment tended to increase the dimensional stability and mechanical properties of B-OSB from andong and betung. The results showed that the dimensional stability and bending strength of B-OSB from betung was higher than those of andong. The internal bond strength of B-OSB from andong was higher than betung owing to a greater amount of extractives dissolved during the steam treatment.
\end{abstract}

Keywords : bamboo, Dendrocalamus asper, Gigantochloa psedoarundinacea, oriented strand board, steam treatment

\section{INTRODUCTION}

Bamboo resources in Indonesia is abundant and have a big potential for new products developement. Bamboo plantation in Indonesia in 2000 was $2,104,000$ ha, consisted of 690,000 ha in permanent forest and 1,414,000 ha in non-forest areas (FAO and INBAR, 2005).

1 Date Received October 16, 2017, Date Accepted November 16, 2017

2 Department of Forest Products, Faculty of Forestry, Bogor Agricultural University, IPB Dramaga Campus, Bogor, 16680, Indonesia

3 Department of Forestry, Faculty of Agriculture, University of Lampung, Jalan Sumantri Brojonegoro 1, Bandar Lampung 35145, Indonesia

4 School of Life Sciences and Technology, Institut Teknologi Bandung, Jalan Ganesha 10 Bandung 40132, Indonesia

5 Department of Forest Biomaterials Engineering, College of Forest and Environmental Science, Kangwon National University, Chuncheon 24341, Republic of Korea

† Corresponding author: Author: Fauzi Febrianto (e-mail: febrianto76@yahoo.com, ORCID: 0000-0002-0964-2179)

${ }^{\dagger}$ Corresponding author: Author: Nam Hun Kim (e-mail: kimnh@kangwon.ac.kr, ORCID: 0000-0002-4416-0554) 
Widjaya (2012) reported that there were 160 bamboo species consisted of 122 endemic species and 38 exotic species. Compared to wood, bamboo has fast growth rate, abundant potency, short cycle, and adaptable to most of soil types except soil in the beach area. In addition, the tensile strength of bamboo is comparable to wood. Due to its advantages, bamboo has been used as raw materials for industry, construction, furniture, household equipment, and handicrafts. However, bamboo also has some limitations when they are used for construction material, particularly due to its diameter. The small diameter and thin culm of bamboo made the solid bamboo difficult to be used for panel products that generally needed a long and wide dimensions. In addition, bamboo also has low modulus of rupture and high variability of physical properties, particularly the density in the bottom, middle, and upper parts.

Composite products can be used as alternatives to increase the efficient utilization of bamboo for structural and non-structural applications. Oriented strand board (OSB) is one of the structural composite panels that has been used as a substitution for plywood products. Structural Board Association (2005) defined OSB as structural composite panel made from long and thin strand with the core layer alligned perpendicularly to the back and surface layers and compacted using hot pressing. Our previous studies revealed that the physical and mechanical properties of bamboo OSB (B-OSB) were higher than those of OSB from wood, and met the standard requirement for commercial OSB (Febrianto and Hadi, 2010; Febrianto and Arinana, 2012; Febrianto et al., 2012; Adrin et al., 2013; Febrianto et al., 2013; Febrianto et al., 2014).

The properties of particleboard and OSB are affected by wood species, density, strand dimensions, strand pre-treatment, particle orientation, resin type and content, layer orientation, pressing parameters, moisture content and board density, and density profile of the board (Maloney, 1993). The extractive content of bamboo, particularly the carbohydrates and sugars content is relatively higher than wood (Fatriasari and Hermiati, 2008; Zhang, 1995). Carbohydrates and sugars are food sources for wood-damaging agents such as wood-decaying fungi, moulds, wood-destroying insects or marine borers which make bamboo susceptible to be attacked by such damaging agents (Febrianto et al., 2013). Pretreatment on strands can be applied to solve the problem, such as steam treatment.

Conventionally, steam treatment is generally applied for solid bamboo during the production of bending products to soften its tissues, hence bamboo becomes easier to be bended into desired form. Steam treatment could improve the durability of bamboo againts degrading agents (Liese, 1987). During steam process, free sugars in lignocellulosic materials is converted into intermediate furane and furane resin to improve the board properties (Rowell et al., 2002). Steam treatment of strands has been reported to improve the properties of OSB from sentang (Melia excelsa) wood (Iswanto et al., 2010). In 
our previous study, we reported the properties of B-OSB from steam-treated bamboostrand binded with isocyanate resin (Febrianto et al., 2015). However, the effects of strand steam treatment on the properties of B-OSB binded with formaldehyde-based resin has not been reported. Therefore, the objective of this study is to evaluate the properties of B-OSB with and without steam treatment, using PF resins as adhesives.

\section{MATERIALS and METHODS}

\subsection{Materials}

Two bamboo species, i.e. andong (Gigantochloa psedoarundinacea) and Betung (Dendrocalamus asper) were obtained from 3-year-old bamboo plantation in Sukabumi, West Java, Indonesia. PF resin was used as a binder. Chemical reagents were used for the determination of differeent extractive contens. Main equipments used in this study are band saw, circular saw, planer, disk flaker, kiln drying furnace, shieve, water bath, oven drier, digital weight scale, moisture meter, glue blending drum, spray gun, strand orienter, forming device, caliper, hot press, and universal testing machine (UTM) instron.

\subsection{Methods}

\subsubsection{Strand Preparation and B-OSB Manufacture}

Bamboo culms without internodes were converted into strands using disk flaker. The strands were treated with steam at $126^{\circ} \mathrm{C}$ for 1 $\mathrm{h}$ under a pressure of $0.14 \mathrm{MPpa}$. Strands were air dried for a week then oven dried at $60-80{ }^{\circ} \mathrm{C}$ for 3 days until reaching moisture content of less than $5 \%$. Three-layer B-OSBs were made with the dimension of $30 \times 30 \times 0.9 \mathrm{~cm}^{3}$ (length $\times$ width $\times$ thickness) using a face-to-core layer ratio of $1: 1: 1 \leftrightarrow$ change this to a face to core rartio such as $60: 40,55: 45$ ). The target board density was $0.7 \mathrm{~g} / \mathrm{cm}^{3}$. PF resin was used as a binder with the solid content of $42 \%$ and resin content of $8 \%$. An addition of $1 \%$ wax was used. The strands were then hot pressed at $135^{\circ} \mathrm{C}$ under a pressure of $25 \mathrm{kgf} / \mathrm{cm}^{2}$. The resulted B-OSBs were conditioned for two weeks under room temperature $\left(25-30^{\circ} \mathrm{C}\right)$ until reaching a constant weight.

\subsubsection{Strand Geometry Measurement}

Strand geometry was measured using 100 strands that obtained randomly. Dimensions of strands such as length, width, and thickness were measured. The slenderness ratio (SR) and aspect ratio (AR) of the strands were determined according to the method described by Maloney (1993).

\subsubsection{Extractive Isolation}

The extractive content of bamboo strands before and after steam treatment was analyzed in accordance with TAPPI standards. Samples were extracted using alcohol-benzene solvent following the procedure of TAPPI T 204 om- 88 (TAPPI 1991). 


\subsubsection{Physical and Mechanical Properties Evaluation}

The physical and mechanical properties of B-OSB were evaluated according to the procedure of JIS A 5908-2003 (JIS 2003) for particleboards. The physical properties evaluated were density, moisture content (MC), water absorption (WA), and thickness swelling (TS), while mechanical properties evaluated were modulus of rupture (MOR), modulus of elasticity (MOE), and internal bond (IB) strength.

\section{RESULTS and DISCUSSION}

\subsection{Geometry of Bamboo Strands}

Strand geometry is a prime parameter affecting both board properties and its manufacturing process. Suchsland and Woodson (1990) suggested that strand geometry is of greater significance in the development of board properties than the actual mechanical properties of the strands themselves. It has a definite relationship with the compression ratio, and thus it will influence the density of composite board. The strands manufactured have satisfactory geometry, showing high values of slenderness ratio (SR) and aspect rato (AR) as shown in Fig. 1. The average SR of strands from andong and betung were higher than 100 and classified as high SR (Febrianto et al., 2015). Strands with high values of SR affected on a better contact between strands and improved strength properties of the boards (Maloney, 1993). The average $\mathrm{AR}$ of strands from andong and betung were greater than 3. Maloney (1993) stated that wood strand having aspect ratio greater than one are easily oriented during forming process. According to Shuler et al. (1976) and Kuklewski et al. (1985), strand aspect ratio of two is enough to produce OSB with superior properties.

\subsection{Extractive content}

The results of extractive analysis showed that the extractive content of andong and betung decreased by steam treatment (Table 1). Steam treatment caused the loosening and softening of cell walls, resulted in the reduction of extractive content. Donohoe (2008) stated that during steam process, the heat and pressure applied increased the porosity of cell walls (Donohoe, 2008). Miranda et al. (1978) added that steam could cause depolymeration and repolymeration of lignin. This caused the extraction of extractive decreased in the bamboo strands.

\subsection{Physical properties of $\mathrm{B}-\mathrm{OSB}$}

The density of particleboard is affected by the density of the raw materials, which makes a contribution to the physical and mechanical propeties of the board (Tsoumis, 1991). The densities of the manufactured B-OSBs were ranging between $0.70-0.73 \mathrm{~g} / \mathrm{cm}^{3}$ and $0.71-0.72$ $\mathrm{g} / \mathrm{cm}^{3}$ for andong and betung, respectively. The results of analysis of variance (ANOVA) at a significance level of 0.05 showed no significant density difference between bamboo species and 
Sena Maulana $\cdot$ Imam Busyra $\cdot$ Adesna Fatrawana $\cdot$ Wahyu Hidayat $\cdot$ Rita Kartika Sari $\cdot$ Ihak Sumardi $\cdot$ I Nyoman Jaya Wistara $\cdot$ Seung Hwan Lee $\cdot$ Nam Hun Kim $\cdot$ Fauzi Febrianto

Table 1. Extractive content of andong and betung bamboos before and after the steam treatment

\begin{tabular}{cccc}
\hline \multirow{2}{*}{ Bamboo species } & Extractive type & \multicolumn{2}{c}{ Strand treatment } \\
\cline { 3 - 4 } & Water-soluble (\%) & 4.29 & 3.95 \\
\hline \hline \multirow{3}{*}{ Andong } & Hot water-soluble (\%) & 5.81 & 5.64 \\
& $1 \%$ NaOH soluble (\%) & 22.57 & 19.29 \\
& Ethanol-benzene-soluble (\%) & 3.20 & 3.11 \\
\hline \multirow{2}{*}{ Betung } & Water-soluble (\%) & 5.63 & 6.62 \\
& Hot water-soluble (\%) & 7.64 & 6.45 \\
& 1\% NaOH soluble (\%) & 19.43 & 18.51 \\
\end{tabular}

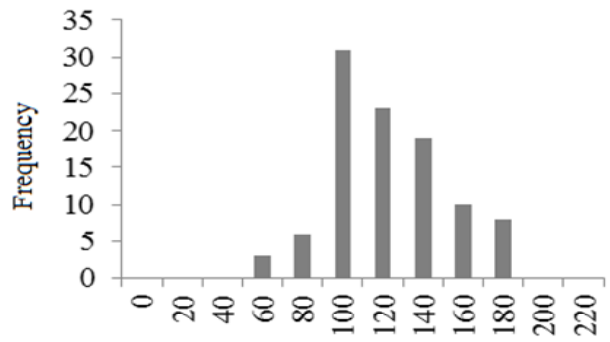

Slenderness ratio

(A)

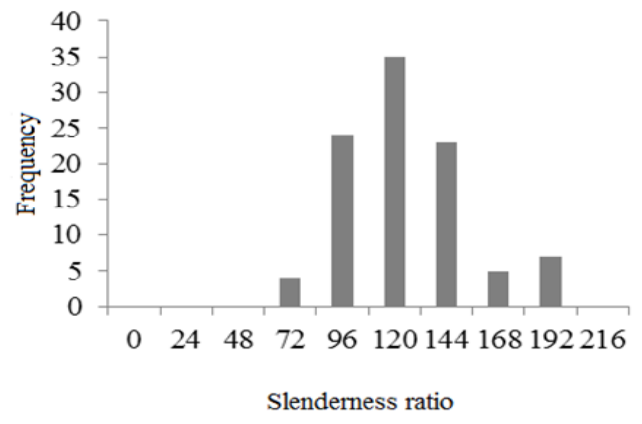

(B)

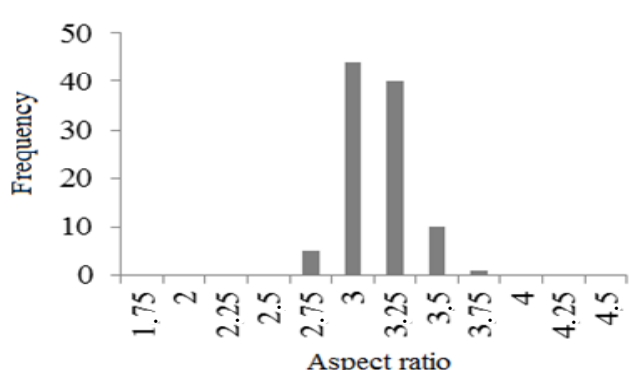

(A)

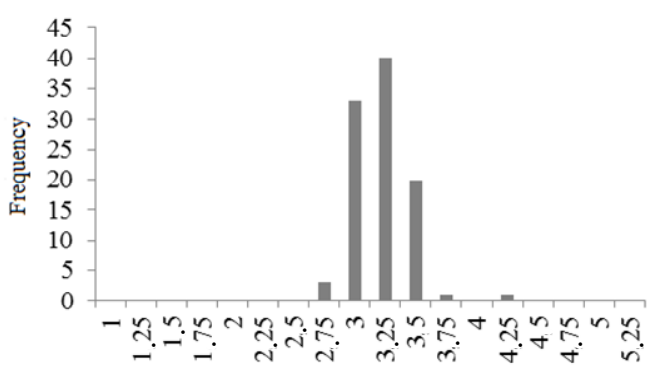

Aspect ratio

(B)

Fig. 1. Aspect ratio and slenderness ratio of the strands from andong (A) and betung (B) bamboo.

strand treatment.

The moisture content (MC) values of B-OSBs from andong were ranging between $9.38 \%$ and $10.38 \%$, while betung between $9.38 \%$ and $10.33 \%$. B-OSBs of both bamboo species were relatively homogeneous, showing no significant differences in the MC values between species and strand treatment.

Water absorption (WA) and thickness swelling (TS) are of the important parameters to evaluate the dimensional stability of composite panels. WA shows the ability of board to ab- 


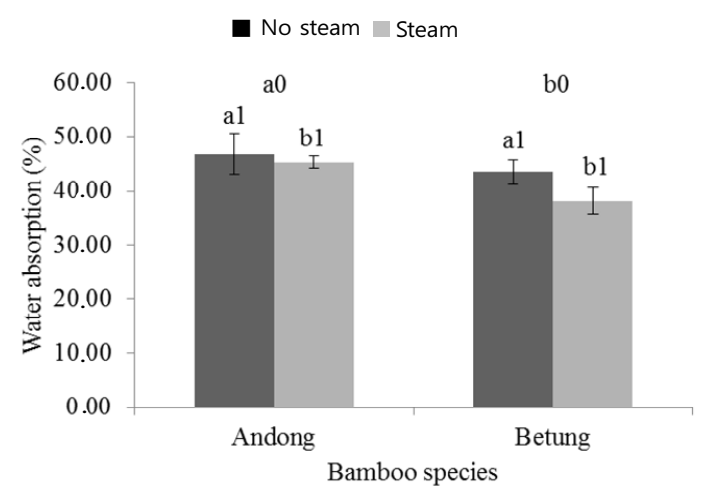

(A)

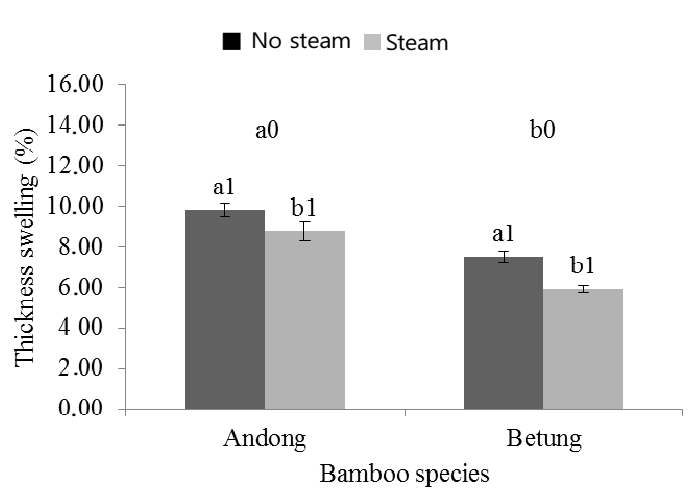

(B)

Fig. 2. Water absorption (A) and thickness swelling (B) of B-OSBs from andong and betung with and without steam treatment; different letter showed a significant difference; 0: bamboo species; 1: strand treatment.

sorp water due to adsoption force, which is the captive force of water molecules in the hydrogen bonds located in cellulose, hemicellulose and lignin. WA values after $24 \mathrm{~h}$ of water immersion were ranging between $45.35-46.82 \%$ and $38.18-43.56 \%$ for B-OSBs from andong and betung, respectively (Fig. 2a). The results of ANOVA revealed that bamboo species and strand treatment contributed significant effects on the WA property, while the interaction between species and strand treatment showed no significant effect. TS values after $24 \mathrm{~h}$ of water immersion were ranging between 8.77-9.82\% and $5.91-7.50 \%$ for B-OSBs from andong and betung, respectively (Fig. 2b). The results of ANOVA revealed that bamboo species and strand treatment contributed significant effects on TS values, while the interaction between species and strand treatment showed no significant effect.

Steam treatment of strands reduced the WA and TS of the B-OSBs from andong and betung. It was believed that the removal of ex- tractives in bamboo due to steam treatment improved the penetration of resin into the strand. The improved bondability of strands resulted in a decrease in the WA of B-OSBs. B-OSBs from betung had lower WA and TS values compared to those of andong due to distinctive anatomical structures between these two species. Andong has vascular bundle type III, while betung has vascular bundle type IV with a relatively higher content of holocellulose and lignin (Liese, 1998). Lignin in the structure of wood and other lignocellulosic materials acts as a thermoplastic binder that can enhance the bond between fibers, and improves the dimensional stability of composite panels. In addition, the extractive contents in andong and betung might also be ascribed to the hygroscopic behaviour of the B-OSBs.

\subsection{Mechanical Properties of B-OSB from Andong and Betung}

MOE shows the ability of a material to main- 


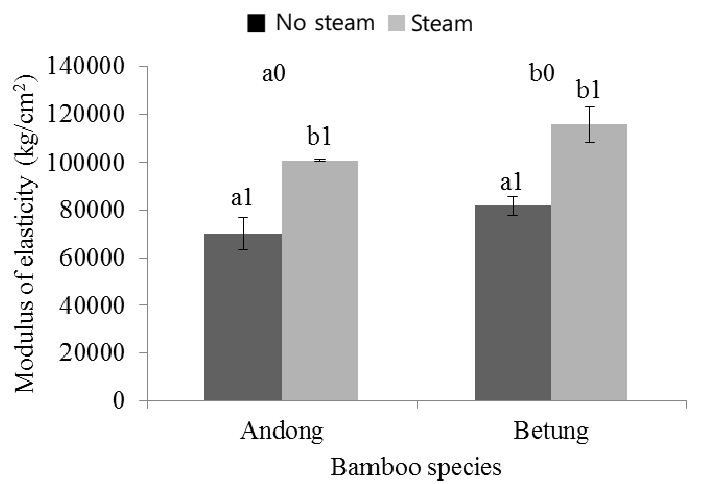

(A)

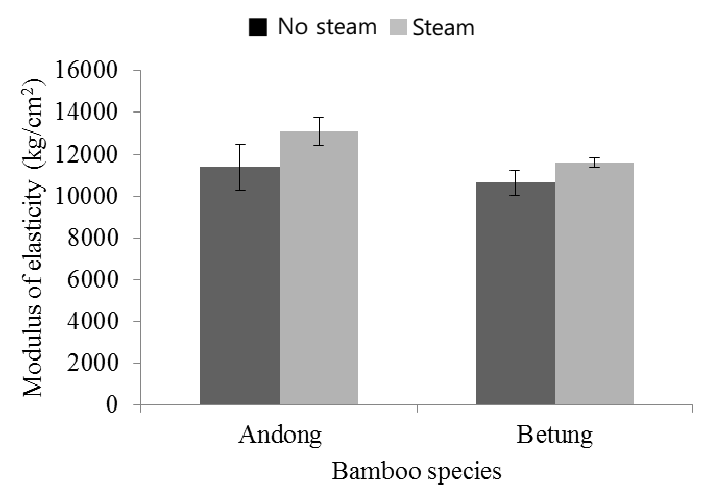

(B)

Fig. 3. MOE parallel (A) and MOE perpendicular (B) to the grain of B-OSBs from andong and betung bamboo with and without the steam treatment; different letters showed a significant difference; 0: bamboo species; 1: strand treatment.

tain its original form during loading. MOE values parallel to the grain direction of B-OSBs were ranging between $70131-100965 \mathrm{~kg} / \mathrm{cm}^{2}$ and $81831-115610 \mathrm{~kg} / \mathrm{cm}^{2}$ for andong and betung, respectively (Fig. 3a). By contrast, the MOE values perpendicular to the grain direction of B-OSBs were ranging between 11407-13097 $\mathrm{kg} / \mathrm{cm}^{2}$ and $10662-11625 \mathrm{~kg} / \mathrm{cm}^{2}$ for andong and betung, respectively (Fig. 3b). The results of ANOVA showed that bamboo species and strand treatment had significant effects to MOE values in both parallel and perpendicular direction, while the interaction between species and strand treatment was insignificant.

MOR shows the maximum load that can withstand by a materials. MOR values parallel to the grain of B-OSBs were ranging between $394-696 \mathrm{~kg} / \mathrm{cm}^{2}$ and $524-763 \mathrm{~kg} / \mathrm{cm}^{2}$ for andong and betung, respectively (Fig. 4a). The results from ANOVA showed that bamboo species and strand treatment contributed significant effects on MOR values parallel to the grain direction. MOR values perpendicular to the grain of B-OSBs were ranging between $119-211 \mathrm{~kg} / \mathrm{cm}^{2}$ and $157-242 \mathrm{~kg} / \mathrm{cm}^{2}$ (Fig. 4b). The ANOVA results showed that the interaction between species and strand treatment had significant effects on MOR values perpendicular to the grain direction. The results revealed that bamboo species and strand treatment affected the bending strength of B-OSBs including MOE and MOR. Steam treatment decreased the extractive content of andong and betung (Table 1), resulting in a better strand adhession. Maloney (1993) explained that extractives could interrupt the penetration of adhessive into materials, causing a decrease of mechanical properties.

Steam treatment of strands improved the bending strength parallel and perpendicular to the grain of B-OSBs from andong and betung. B-OSBs from betung strands showed better bending strength compared to andong due to 
No steam Steam

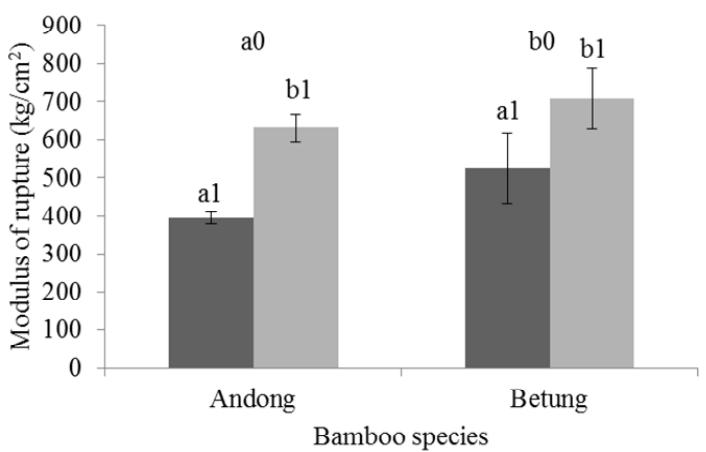

(A)

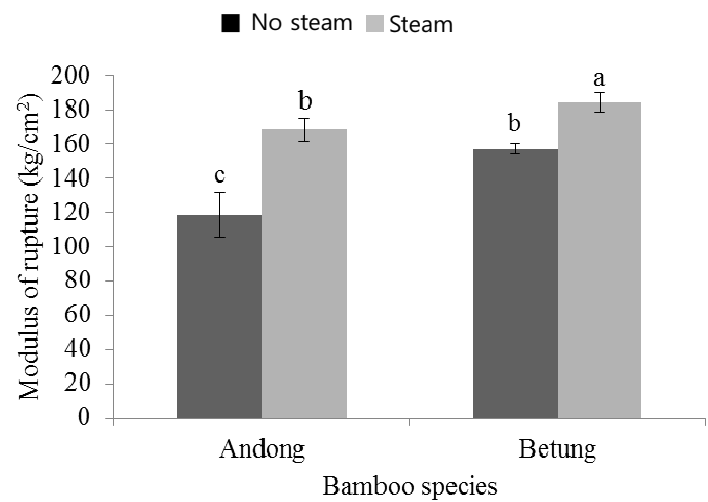

(B)

Fig. 4. MOR parallel to the grain (a) and MOR perpendicular to the grain (B) of B-OSBs from andong and betung with and without steam treatment; different letter showed a significant difference; 0 : bamboo species; 1: strand treatment.

the differences in anatomical structure and the initial density of the bamboos. As described earlier in this paper, andong has vascular bundle type III, while betung has vascular bundle type IV. Latif et al. (1990) and Nuryatin (2012) reported that vascular bundle attributed to the values of MOE and MOR. The initial density of andong and betung were $0.72 \mathrm{~g} / \mathrm{cm}^{3}$ and $0.66 \mathrm{~g} / \mathrm{cm}^{3}$, respectively. With the target B-OSB density of $0.7 \mathrm{~g} / \mathrm{cm}^{3}$, the compression ratio of B-OSB from betung was significantly higher than that of B-OSB from andong, resulting in a better bending strength values. The results were in a good agreement with those of Sumardi et al. (2006) that evaluated the relationship between compression ratio and bending strength of OSB from moso (Phyllostachys pubescens) bamboo.

IB strength, or the tensile strength perpendicular to the plane of the panel is one of the important strength properties of composite panels.
The IB strength values were ranging between $4.01-5.62 \mathrm{~kg} / \mathrm{cm}^{2}$ and $3.89-4.73 \mathrm{~kg} / \mathrm{cm}^{2}$ for $\mathrm{B}-\mathrm{OSBs}$ from andong and betung, respectively (Fig. 5). The results of ANOVA showed that bamboo species and strand treatment had significant effects on the IB strength values of B-OSBs. Steam treatment of the strands improved the IB values of B-OSBs from andong and betung. Steam treatment could convert free sugars in woody materials into furan intermediates, which can be further converted into furan resins, causing an improvement of mechanical properties and the dimensional stabilization of boards (Rowell et al., 2002).

According to Maloney (1993), the extractive in woody materials can cause a problem during particleboard production due to its negative effect on the penetration of adhessive into particles. Steam treatment effectively reduced the extractive content of andong and betung, resulting in a better penetration of adhesive into 


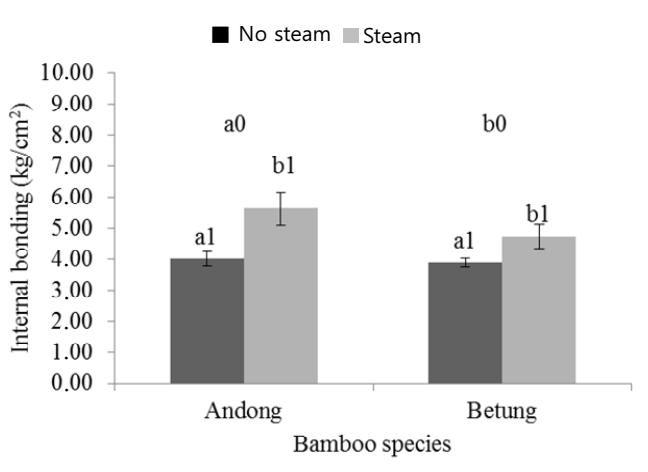

Fig. 5. Internal bond strength of B-OSBs from andong and betung with and without steam treatment; different letter showed a significant difference; 0 : bamboo species; 1: strand treatment.

strands and an improvement of strength properties of B-OSBs. The increase of IB values of B-OSB from andong with steam was relatively higher than that of B-OSB from betung. This might be due to more extractive dissolved from andong compared to betung. Table 1 shows that $\mathrm{NaOH}$-soluble extractive of andong decreased more significantly compared to betung.

\section{CONCLUSION}

The geometry of strands produced from andong and betung bamboo were satisfactory, showing high slenderness and aspect ratio. Steam treatment of strands significantly reduced the extractive content, and thus improved the dimensional stability and mechanical properties of B-OSBs from andong and betung strands with superior properties of B-OSBs after the treatment than those of B-OSBs without the treatment. A simple and relatively low-cost steam treatment of strands offers a promising alternative treatment to produce B-OSB with high dimensional stability and mechanical properties.

\section{ACKNOWLEDGEMENT}

We sincerely acknowledge the Doctoral Programme for Outstanding Undergraduate Students Secretariat (No.330/SP2H/LT/DRPM/IX/2016, 8 September 2016), Directorate of Higher Education (DIKTI), Ministry of Research, Technology, and Higher Education, Republic of Indonesia due to the financial support given.

\section{REFERENCES}

Adrin, Febrianto, F., Sadiyo, S. 2013. Properties of oriented strand board prepared from steam treated bamboo strands under various adhesive combinations. Jurnal Ilmu dan Teknologi Kayu Tropis 11(2): 109 119.

Donohoe, B.S., Decker, S.R., Tucker, M.P., Himmel, M.E., Vinzant, T.B. 2008. Visualizing lignin coalescence and migration through maize cell walls following thermochemical pretreatment. Biotechnology and Bioengineering 101(5): 913 925.

FAO, INBAR. 2005. Global forest resources assessment update 2005. Indonesia. CountryReport on Bamboo Resources. Forest Resources Assessment Programme Working Paper (Bamboo). Food and Agriculture Organization of the United Nation (FAO), Forestry Department and International Network for Bamboo and Rattan. Jakarta, May, 2005.

Fatriasari, W., Hermiati, E. 2008. Analisis morfologi serat dan sifat fisis-kimia pada enam jenis bambu sebagai bahan baku pulp dan kertas. Jurnal Ilmu dan Teknologi Hasil Hutan 1(2): 67 72.

Febrianto, F., Gumilang, A., Maulana, S., Busyra, I., 
Purwantiningsih, A. 2014. Natural durability of five bamboo species against termite and powder post beetle. Jurnal Ilmu dan Teknologi Kayu Tropis 12(2): 146 156.

Febrianto, F., Purnamasari, I., Arinana, Gumilang, A., Kim, N.H. 2013. Steaming effect on natural durability of bamboo oriented strand board against termites and power post beetle. Jurnal Ilmu dan Teknologi Kayu Tropis 11(2): 161 169.

Febrianto, F., Sahroni., Hidayat, W., Bakar, E.S., Kwon, G.J., Kwon, J.H., Kim, N.H. 2012. Properties of oriented strand board made from betung bamboo (Dendrocalamus asper (Schultes.f) Backer ex Heyne). Wood Science and Technology 46: $53 \sim 62$.

Febrianto, F., Hidayat, W., Samosir, T.P., Lien, H.C., Song, H.D. 2010. Effect of strand combination on dimensional stability and mechanical properties of oriented strand board made from tropical fast growing species. Journal of Bio-Science 10(3): $267 \sim 272$.

Febrianto, F., Hadi, Y.S., Kim, N.H. 2010. Pengembangan oriented strand board unggul dari beberapa jenis bambu untuk komponen bangunan bermutu struktural. Seminar Hasil-Hasil Penelitian IPB, Bogor, 13-14 Desember, 2010.

Febrianto, F., Jang, J.H., Lee, S.H., Santosa, I.A., Hidayat, W., Kwon, J.H., Kim, N.H. 2015. Effect of bamboo species and resin content on properties of oriented strand board prepared from steam-treated bamboo strands. Bioresources 10(2): $2642 \sim 2655$.

Iswanto, A.H., Febrianto, F., Wahyudi, I., Hwang, W.J., Lee, S.H., Kwon, J.H., Kwon, S.M., Kim, N.H., Kondo, T. 2010. Effect of Pre-treatment Techniques on Physical, Mechanical and Durability Properties of Oriented Strand Board Made from Sentang wood (Melia excelsa Jack).
JIS A 5908 (2003). "Standards on Particleboard," Japanese Standards Association, Tokyo, Japan.

Kuklewski, K.M., Blankenhorn, P.R., Rishel, L.E. 1985. Comparison of selected physical and mechanical properties of red maple (Acer rubrum L.) and aspen (Populus grandidentata Michx.) flakeboard. Wood and Fiber Science 17(1): $11 \sim 21$.

Latif, A.M., Wan, Tarmeze, W.A., Fauzidah A. 1990. Anatomical features and mechanical properties of three Malaysian bamboos. Journal Tropical Forest Science 2(3): 227 234.

Liese, W. 1987. Anatomy and properties of bamboo. In: Rao, AN, G. Dhanarajan, C,B, Sary, ed. Recent research on bamboo. Proceeding of international bamboo workshop, Hangzholu, People's Republic of China, Oct 4-14, 1985. Academy of Forestry, People's Republic of China \& International Development Research Centre, Canada, pp. 196 208.

Liese, W. 1998. The Anatomy of Bamboo Culm, Technical Review, International Network for Bamboo and Rattan, People's Republic of China, pp. $36 \sim 42$.

Maloney, T.M. 1993. Modern particleboard and dry-process fibreboard manufacturing. Forest Products Society, Madison. WI.

Miranda, G.S., Wayman, M. 1979. Characterization of autohydrolysis aspen (P. tremuloides) lignins, Part 1. Composition and molecular weight distribution of extracted autohydrolysis lignin. Canadian Journal of Chemistry 57: 1141 1149. Nuryatin, N. 2012. Vascular bundle pattern as predictor of bamboo utilization. Dissertation. Graduate School of Bogor Agricultural University (IPB), Bogor.

Rowell, R.M., Lange, S., McSweeny, J., Davis, M. 2002. Modification of wood fiber using steam. Proceeding of 6th Rim Bio-Based Composites 
Symposium. Oregon, USA.

Structural Board Association. 2005. Oriented strand board in wood frame construction. Ontario (CA): Structural Board Association.

Sumardi, I., Suzuki, S., Ono, K. 2006. Some important properties of strand board manufactured from bamboo. Forest Products Journal 56(6): $59 \sim 63$.

Technical Association of the Pulp and Paper Industry. 1991. TAPPI Test methods. Vol.1. Atlanta: TAPPI Press. Berlian NV, Rahayu E. 1995. Jenis dan Prospek Bisnis Bambu. Jakarta (ID): PT Penebar Swadaya.

Tsoumis, G. 1991. Science and technology of wood:
Structure, properties utilization. New York: Van Nostrand Reinhold.

Widjaya, E.A. 2012. The Utilization of bamboo: At present and for the future. Proceedings of International Seminar Strategies and Challenges on Bamboo and Potential Non Timber Forest Products (NTFP) Management and Utilization. 23-24 November 2011, Bogor, Indonesia 79-85. Center for Forest Productivity Improvement Research and Development. Bogor. Indonesia.

Zhang, Q. 1995. To scientifically and reasonably utilize Chinese bamboo resources. Wood Process. Machin 6(4): 23 32. 